\title{
The seasonal variations of allelopathic activity and allelopathic substances in Brachiaria brizantha
}

\author{
Ai Kobayashi and Hisashi Kato-Noguchi
}

\begin{abstract}
Background: Controlling weeds through allelopathy is one strategy to reduce dependency on synthetic herbicides. The plant shoots of the grass Brachiaria brizantha incorporated into the field soil were found to inhibit the growth of several plant species. We investigated the variations of allelopathic activity and allelopathic substances in $B$. brizantha harvested in June, October and January.

Results: All extracts of B. brizantha obtained from June, October and January inhibited the root and shoot growth of cress, lettuce, Phleum pretense and Lolium multiflorum in a concentration dependent manner. However, the inhibitory activity of $B$. brizanth $a$ of June and October was greater than that of $B$. brizantha of January. Concentrations of three potent allelopathic active substances, (6R,9S)-3-oxo- $\alpha$-ionol, $(6 R, 9 R)$-3-oxo- $\alpha$-ionol and 4-ketopinoresinol were also greater in B. brizantha of June and October than those in B. brizantha of January.

Conclusion: The results suggest that the allelopathic activity and the levels of those allelopathic active substances are greater in B. brizantha of June and October than those in B. brizantha of January. It is possible that B. brizantha could be useful for a weed suppressive residue or soil additive materials in the variety of agricultural settings to develop sustainable agriculture options. The effectiveness of $B$. brizantha of June and October as a weed suppressive agent may be greater than that of January.
\end{abstract}

Keywords: Allelopathy, Brachiaria brizantha, Growth inhibitor, Phytotoxicity, Soil additive

\section{Background}

Plant allelopathy has been investigated for long time to develop sustainable agricultural systems especially in weed control purposes (Belz 2007; Macías et al. 2007). Plants contain hundreds of secondary metabolites, and some of those compounds showed strong allelopathic activity such as germination and growth inhibitory effects on other plants (Inderjit 1996; Duke et al. 2000; Macías et al. 2007). Some plant materials and residues incorporated into field soil provided excellent weed control ability due to the allelopathic active substances in those materials. Intercropping of allelopathic plants with crop plants also inhibited weed germination and growth owing to their allelopathic property (Weston 1996;

\footnotetext{
*Correspondence: hisashi@ag.kagawa-u.ac.jp

Department of Applied Biological Science, Faculty of Agriculture, Kagawa University, Miki, Kagawa 761-0795, Japan
}

Narwal 1999). Therefore, plant allelopathy is probably useful for weed management options in the sustainable agricultural settings (Putnam 1988; Weston 1996; Narwal 1999).

Poaceae species Brachiaria brizantha, originating in Africa savannas, is introduced into many countries as livestock forage (McGregor et al. 1988). The extracts of B. brizantha shoots inhibited the seed germination of Stylosanthes species (Rodrigues et al. 2012) and seedling growth of cress, lettuce, Phleum pratense and Lolium multiflorum (Kato-Noguchi et al. 2014). In addition, the plant shoots of B. brizantha incorporated into the field soil inhibited the growth of several plant species (Martins et al. 2006; Souza et al. 2006). Three allelopathic active substances, $(6 R, 9 S)$-3-oxo- $\alpha$-ionol, $\quad(6 R, 9 R)-3$ oxo- $\alpha$-ionol and 4-ketopinoresinol were isolated from $B$. brizantha shoots (Kato-Noguchi et al. 2014). Therefore,

\section{Springer}

(c) 2015 Kobayashi and Kato-Noguchi. This article is distributed under the terms of the Creative Commons Attribution 4.0 International License (http://creativecommons.org/licenses/by/4.0/), which permits unrestricted use, distribution, and reproduction in any medium, provided you give appropriate credit to the original author(s) and the source, provide a link to the Creative Commons license, and indicate if changes were made. 
B. brizantha shoots may be also useful as soil additives for weed management options in some sustainable agricultural settings because of their allelopathic active substances.

B. brizantha is a perennial grass, $1-2 \mathrm{~m}$ in height, with $2 \mathrm{~m}$ deep roots and rhizomes. The plant shoots with long leaf blades grow from spring to autumn and die in winter (Miles et al. 1996; Cook et al. 2005). Therefore, it is important to evaluate the variations of the allelopathic activity and the levels of allelopathic active substance in $B$. brizantha for soil additive materials. However, there is no information available about those variations. In the present research, allelopathic activity of B. brizantha shoots and the level of allelopathic active substances in the shoots were determined in June, October and January.

\section{Methods}

\section{Plant materials}

Brachiaria brizantha (Hochst. ex A. Rich.) Stapf. (common name; palisade grass, bread grass, syn; Urochloa brizantha Hochst. ex A. Rich.) was grown in the research field of National Institute for Agro-Environmental Sciences, Tsukuba, Japan. Shoots of the plants were harvested in June and October 2011 and January 2012, and stored at $-20{ }^{\circ} \mathrm{C}$ until extraction. Cress (Lepidum sativum L.) and lettuce (Lactuca sativa L.) were used due to their uniform establishment and sensitivity as a seedling indicator (Kato-Noguchi et al. 2010, 2014). Weed species, Phleum pratense L. and Lolium multiflorum Lam were also used for bioassay.

\section{Extraction and bioassay}

B. brizantha (100 g dry weight) shoots were extracted with $1 \mathrm{~L}$ of $70 \%(\mathrm{v} / \mathrm{v})$ aqueous methanol for 2 days. After filtration with filter paper (No. 2; Toyo, Tokyo, Japan), the residue was extracted again with $1 \mathrm{~L}$ methanol for 2 days and filtered, and the two filtrates were combined. An aliquot of the extract (final assay concentration of tested samples corresponded to the extracts obtained from 0.3, 1, 3, 10, 30, 100 and $300 \mathrm{mg}$ dry weight of $B$. brizantha shoots per $\mathrm{mL}$ ) was evaporated to dryness, dissolved in a $0.2 \mathrm{~mL}$ of methanol and added to a sheet of filter paper (No. 2) in a 3-cm Petri dish. The methanol was evaporated in a fume hood. Then, the filter paper in the Petri dishes was moistened with $0.8 \mathrm{~mL}$ of $0.05 \%(\mathrm{v} / \mathrm{v})$ polyoxyethylene sorbitan monolaurate (Tween 20 ). Ten seeds of cress or lettuce, or 10 seedlings of $P$ pratense or $L$. multiflorum after germination in the darkness at $25{ }^{\circ} \mathrm{C}$ for 36-48 $\mathrm{h}$ were placed in the Petri dishes. The length of roots and shoots of these seedlings were measured after $48 \mathrm{~h}$ of incubation in the darkness at $25^{\circ} \mathrm{C}$. Controls were treated exactly as described above, with the exception that $0.2 \mathrm{~mL}$ methanol was used instead of B. brizantha extracts. Inhibitory activity (\%) was determined by the formula: [(control plant length - plant length incubated with extract)/control plant length] $\times 100$. The bioassay was repeated five times using a randomized design with 10 plants for each determination. Significant differences were examined by Duncan's multiple comparison tests.

\section{Quantification of allelopathic active substances}

Brachiaria decumbens shoots was extracted as described above and the extracts were concentrated at $40{ }^{\circ} \mathrm{C}$ in vacuo to produce an aqueous residue. The aqueous residue was adjusted to $\mathrm{pH} 7.0$ with $1 \mathrm{M}$ phosphate buffer and partitioned three times against an equal volume of ethyl acetate as described by Kato-Noguchi et al. (2014). The ethyl acetate fraction was evaporated to dryness and separated on a column of silica gel $(100 \mathrm{~g}$, silica gel 60 , 70-230 mesh; Merck), eluted with 20, 30, 40, 50, 60, 70 and $80 \%$ ethyl acetate in $n$-hexane $(100 \mathrm{~mL}$ per step) and ethyl acetate $(100 \mathrm{~mL})$. Allelopathic active substances, $(6 R, 9 R)-3$-oxo- $\alpha$-ionol and $(6 R, 9 S)$-3-oxo- $\alpha$-ionol, were obtained by the elution with $70 \%$ ethyl acetate in $n$-hexane on the silica gel column, and 4-ketopinoresinol was obtained by the elution with $80 \%$ ethyl acetate in $n$-hexane on the silica gel column (Kato-Noguchi et al. 2014).

For quantification of $(6 R, 9 R)-3$-oxo- $\alpha$-ionol and $(6 R, 9 S)$-3-oxo- $\alpha$-ionol, the fraction obtained with $70 \%$ ethyl acetate in $n$-hexane on the silica gel column was evaporated. The residue was then dissolved in $20 \%(\mathrm{v} / \mathrm{v})$ aqueous methanol $(2 \mathrm{~mL})$ and loaded onto reverse-phase $\mathrm{C}_{18}$ cartridges (YMC Ltd., Kyoto, Japan). The cartridge was eluted with $20,40,60$ and $80 \%(\mathrm{v} / \mathrm{v})$ aqueous methanol (15 mL per step). The active fraction was eluted by $40 \%$ aqueous methanol and evaporated to dryness. The residue was injected into reverse-phase HPLC $(4.6 \mathrm{~mm}$ i.d. $\times 250 \mathrm{~mm}$, Inertsil ODS-3, GL Sciences, Osaka, Japan) eluted at a flow rate of $0.8 \mathrm{~mL} \mathrm{~min}{ }^{-1}$ with $55 \%$ aqueous methanol and detected at $220 \mathrm{~nm}$. Retention time of $(6 R, 9 R)$-3-oxo- $\alpha$-ionol and $(6 R, 9 S)$-3-oxo- $\alpha$-ionol was 65 and $70 \mathrm{~mm}$, respectively. Quantification of those compounds was performed by measuring their peak areas on the chromatogram of HPLC. The quantification was repeated three times independently with three assays for each determination. Significant differences were examined by Duncan's multiple comparison tests.

The ${ }^{1} \mathrm{H}-\mathrm{NMR}$ spectrum of $(6 R, 9 R)-3$-oxo- $\alpha$-ionol, $\delta_{\mathrm{H}}$ : $1.00(3 \mathrm{H}, \mathrm{s}), 1.03(3 \mathrm{H}, \mathrm{s}), 1.24(3 \mathrm{H}, \mathrm{d}, J=6.8 \mathrm{~Hz}), 1.94$ $(3 \mathrm{H}, \mathrm{d}, J=1.0 \mathrm{~Hz}), 2.05(1 \mathrm{H}, \mathrm{d}, J=16.6 \mathrm{~Hz}), 2.40(1 \mathrm{H}$, $\mathrm{d}, J=16.6 \mathrm{~Hz}), 2.67(1 \mathrm{H}, \mathrm{d}, J=9.3 \mathrm{~Hz}), 4.27(1 \mathrm{H}, \mathrm{m})$, $5.58(1 \mathrm{H}, \mathrm{dd}, J=15.1,8.8 \mathrm{~Hz}), 5.70(1 \mathrm{H}, \mathrm{dd}, J=15.2$, $5.9 \mathrm{~Hz}), 5.88(1 \mathrm{H}, \mathrm{s})$. The specific rotation of the compound $\left([\alpha]_{\mathrm{D}}^{25}\right)$ was $+210^{\circ}\left(c 0.03, \mathrm{CH}_{2} \mathrm{Cl}_{2}\right)$. The ${ }^{1} \mathrm{H}-\mathrm{NMR}$ spectrum of $(6 R, 9 S)-3$-oxo- $\alpha$-ionol, $\delta_{\mathrm{H}}: 0.98(3 \mathrm{H}, \mathrm{s}), 1.03$ 
$(3 \mathrm{H}, \mathrm{s}), 1.24(3 \mathrm{H}, \mathrm{d}, J=6.4 \mathrm{~Hz}), 1.96(3 \mathrm{H}, \mathrm{d}, J=1.5 \mathrm{~Hz})$, $2.05(1 \mathrm{H}, \mathrm{d}, J=16.6 \mathrm{~Hz}), 2.42(1 \mathrm{H}, \mathrm{d}, J=17.1 \mathrm{~Hz}), 2.66$ $(1 \mathrm{H}, \mathrm{d}, J=8.8 \mathrm{~Hz}), 4.28(1 \mathrm{H}, \mathrm{m}), 5.55(1 \mathrm{H}, \mathrm{dd}, J=15.1$, $8.8 \mathrm{~Hz}), 5.69(1 \mathrm{H}, \mathrm{dd}, J=15.1,5.9 \mathrm{~Hz}), 5.89(1 \mathrm{H}, \mathrm{s})$. The specific rotation of the compound $\left([\alpha]_{\mathrm{D}}^{25}\right)$ was $+214^{\circ}(c$ $0.05, \mathrm{CH}_{2} \mathrm{Cl}_{2}$ ).

For quantification of 4-ketopinoresinol obtained with $80 \%$ ethyl acetate in $n$-hexane on the silica gel column was evaporated. The residue was then dissolved in $20 \%$ $(\mathrm{v} / \mathrm{v})$ aqueous methanol $(2 \mathrm{~mL})$ and loaded onto reversephase $\mathrm{C}_{18}$ cartridges. The cartridge was eluted with 20 , 40,60 and $80 \%(\mathrm{v} / \mathrm{v})$ aqueous methanol ( $15 \mathrm{~mL}$ per step). The active fraction was eluted by $40 \%$ aqueous methanol and evaporated to dryness. The residue was injected into reverse-phase HPLC $(10 \mathrm{~mm}$ i.d. $\times 50 \mathrm{~cm}$, ODS AQ-325; YMC Ltd.) eluted at a flow rate of $1.5 \mathrm{~mL} \mathrm{~min}^{-1}$ with $40 \%$ aqueous methanol and detected at $220 \mathrm{~nm}$. Retention time of 4-ketopinoresinol was $145 \mathrm{~mm}$ and quantification of the compound was performed by measuring their peak areas as described above.

The ${ }^{1} \mathrm{H}$-NMR spectrum of 4-ketopinoresinol, $\delta_{\mathrm{H}}: 3.25$ (m, $1 \mathrm{H}, \mathrm{H} 1$ ), 3.47 (dd, $J=9.2,3.8 \mathrm{~Hz}, 1 \mathrm{H}, \mathrm{H} 5), 3.90$ (s, 3 $\left.\mathrm{H}, \mathrm{OCH}_{3}\right), 3.92\left(\mathrm{~s}, 3 \mathrm{H}, \mathrm{OCH}_{3}\right), 4.04(\mathrm{dd}, J=9.4,4.5 \mathrm{~Hz}$, $1 \mathrm{H}, \mathrm{H} 8 \mathrm{a}), 4.34$ (dd, $J=9.3,6.8 \mathrm{~Hz}, 1 \mathrm{H}, \mathrm{H} 8 \mathrm{~b}), 5.34$ (d, $J=4.0 \mathrm{~Hz}, 1 \mathrm{H}, \mathrm{H} 2), 5.35(\mathrm{~d}, J=3.6 \mathrm{~Hz}, 1 \mathrm{H}, \mathrm{H} 6), 6.8(\mathrm{~m}$, $2 \mathrm{H}$, aromatic $\mathrm{H}), 6.9(\mathrm{~m}, 4 \mathrm{H}$, aromatic $\mathrm{H})$. The ${ }^{13} \mathrm{C}$ NMR spectrum of the compound, $\delta_{\mathrm{C}}: 50.1$ (C1), 53.5 (C5), 56.2 $\left(\mathrm{OCH}_{3}\right), 56.2\left(\mathrm{OCH}_{3}\right), 72.8(\mathrm{C} 8), 83.5(\mathrm{C} 2), 84.8(\mathrm{C} 6)$, $107.9\left(\mathrm{C}^{\prime}\right), 108.2\left(\mathrm{C}^{\prime \prime}\right), 114.5\left(\mathrm{C}^{\prime \prime}\right), 114.8\left(\mathrm{C}^{\prime}\right), 118.1$ $\left(\mathrm{C6}^{\prime \prime}\right), 118.5\left(\mathrm{C6} 6^{\prime}\right), 131.2\left(\mathrm{C1}^{\prime}\right), 132.4\left(\mathrm{C1}^{\prime \prime}\right), 145.4\left(\mathrm{C}^{\prime \prime}\right)$, $146.2\left(\mathrm{C}^{\prime}\right), 146.9\left(\mathrm{C}^{\prime \prime}\right), 147.1\left(\mathrm{C}^{\prime}\right), 177.1(\mathrm{C} 4)$. The specific rotation of the compound $\left([\alpha]_{\mathrm{D}}^{25}\right)$ was $+5.7^{\circ}(c 0.1$, $\left.\mathrm{CH}_{3} \mathrm{OH}\right)$.

\section{Results and discussion}

Three extracts obtained from $10 \mathrm{mg}$ B. brizantha shoots harvested in June, October and January inhibited the growth of cress roots and shoots (Fig. 1). The inhibitory activity of the June extract on the cress roots and shoots was 76.1 and $79.5 \%$, respectively, that of the October extract on the cress roots and shoots was 55.7 and $71.5 \%$, respectively, and that of the January extract on the cress roots and shoots was 35.8 and $15.8 \%$ respectively. Although $B$. brizantha is perennial plant, its shoots re-start to grow around May and die in November and only its underground parts survive after November. The shoots of the plants were growing stage in June and mature stage in October and both shoots were green. The shoots of January had already died and turned brown (Fig. 2). The results indicate that allelopathic activity of B. brizantha of June and October was greater than that of January. Thus, green plant materials may be better than dead plant materials for a weed suppressive residue or soil additive materials.

Inhibitory activity of $B$. brizantha shoot extracts obtained from June, October and January was determined by root and shoot growth of cress, lettuce, $P$. pretense and L. multiflorum (Fig. 2). All extracts inhibited the growth of the roots and shoots of those test plants with extractconcentration dependent. The concentrations required for $50 \%$ growth inhibition on the roots and shoots of the test plants in the assay (defined as $\mathrm{I}_{50}$ ) were determined by a logistic regression $\left(\mathrm{Y}=\mathrm{b}+\mathrm{a} \log _{10} \mathrm{X}\right.$. Y; \% length, $\mathrm{X}$; concentration, a; slope, $\mathrm{b}$; intercept) analysis (Table 1). Comparing those $\mathrm{I}_{50}$ values, inhibitory activity of the June extract was 1.1- to 1.8-fold and 4.4- to 27.8fold greater than that of the October extract and January extract, respectively. These results suggest that all B. brizantha extracts have inhibitory effects on both dicotyledonous plants (cress and lettuce) and monocotyledonous weed plants (P. pretense and L. multiflorum) and the June extract has the greatest inhibitory activity.

$(6 R, 9 S)$-3-oxo- $\alpha$-ionol, $\quad(6 R, 9 R)$-3-oxo- $\alpha$-ionol and 4-ketopinoresinol were isolated from $B$. brizantha shoots as three major active substances in B. brizantha (KatoNoguchi et al. 2014). Thus, concentrations of those allelopathic active substances, $(6 R, 9 S)$-3-oxo- $\alpha$-ionol, $(6 R, 9 R)-3$-oxo- $\alpha$-ionol and 4-ketopinoresinol were determined in B. brizantha shoots of June, October and January (Fig. 3). Those concentrations in the January shoots were significantly lower than those in the June and October shoots. Concentration of $(6 R, 9 S)-3$-oxo- $\alpha$-ionol, $(6 R, 9 R)-3$-oxo- $\alpha$-ionol and 4-ketopinoresinol in the June shoots was 2.3-, 2.2- and 2.4-fold greater than that in the January shoots, respectively. This result is consistent with the result of inhibitory activity of the shoot extracts of June, October and January (Table 1) and also indicates that June and October shoots may be better than January shoots for a weed suppressive residue or soil additive materials.

$(6 R, 9 S)-3$-Oxo- $\alpha$-ionol, $\quad(6 R, 9 R)-3$-oxo- $\alpha$-ionol and 4-ketopinoresinol inhibited the growth of cress at concentrations greater than 10,30 and $30 \mu \mathrm{M}$, respectively. $\mathrm{I}_{50}$ values on cress roots and shoots were 223 and $156 \mu \mathrm{M}$ for $(6 R, 9 R)-3$-oxo- $\alpha$-ionol, respectively, and 41.7 and $25.1 \mu \mathrm{M}$ for $(6 R, 9 S)-3$-oxo- $\alpha$-ionol, respectively, and 83.5 and $141 \mu \mathrm{M}$ for 4-ketopinoresinol, respectively (Kato-Noguchi et al. 2014). Therefore, the inhibitory activity of $(6 R, 9 S)$-3-oxo- $\alpha$-ionol was 5.3 to 6.2 - and 2 to 5.6 -fold greater than that of $(6 R, 9 R)-3$-oxo- $\alpha$-ionol and 4-ketopinoresinol, respectively. These results indicate that the growth inhibitory activity of $(6 R, 9 S)-3$-oxo- $\alpha$ ionol is the greatest, followed by 4-ketopinoresinol and $(6 R, 9 R)-3$-oxo- $\alpha$-ionol. 

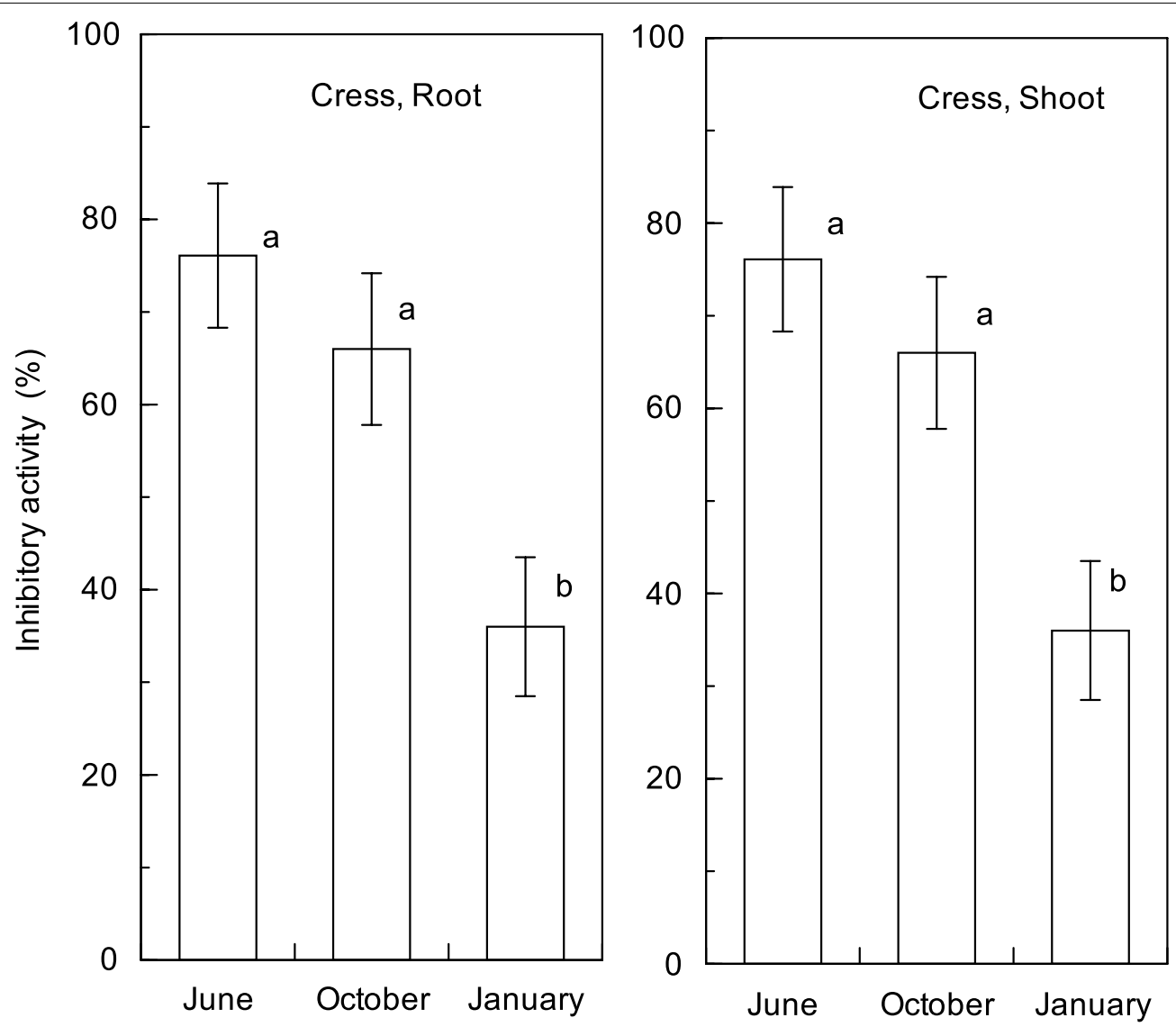

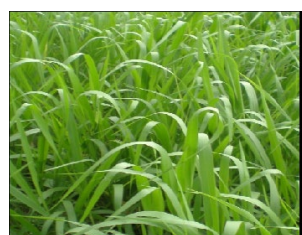

June

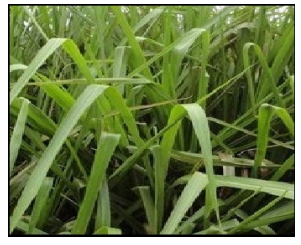

October

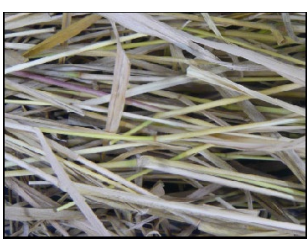

January

Fig. 1 Effects of aqueous methanol extracts of B. brizantha shoots harvested in June, October and January on cress root and shoot growth. Concentration of tested sample corresponded to the extract obtained from $10 \mathrm{mg}$ dry weight of $B$. brizantha per $\mathrm{mL}$. Mean $\pm \mathrm{SE}$ from five independent experiments with ten plants for each determination are shown. The different letters in the same groups indicate significant difference $(P<0.05)$ according to Duncan's multiple comparison tests

3-Oxo- $\alpha$-ionol was first identified as the aglycone of a glucoside isolated from Rubus idaeus (Pabst et al. 1992; D'Abrosca et al. 2004) and was reported to act as allelopathic active substance in rattail fescue (Kato-Noguchi et al. 2010). However, the specific biological activities of $(6 R, 9 R)-3$-oxo- $\alpha$-ionol and $(6 R, 9 S)$-3-oxo- $\alpha$-ionol were first reported by Kato-Noguchi et al. (2014). 4-Ketopinoresinol was first isolated from Aegilops ovate as germination inhibitor (Lavie et al. 1974; Cooper et al. 1977), but the information on the biological activity of the compound is very limited.
Phytotoxic active substances in plants can be released into the soil, either by exudates from living plant tissues or by decomposition of plant residues, and act as allelopathic active substances which inhibit seed germination, seedling establishment and plant growth (Bais et al. 2006; Bonanomi et al. 2006; Belz 2007). The present results showed that $B$. brizantha inhibited root and shoot growth of four test plant species including weed plants $(P$. pretense and L. multiflorum) in a concentration dependent manner. Thus, B. brizantha could be useful for a weed suppressive residue or soil additive materials in 


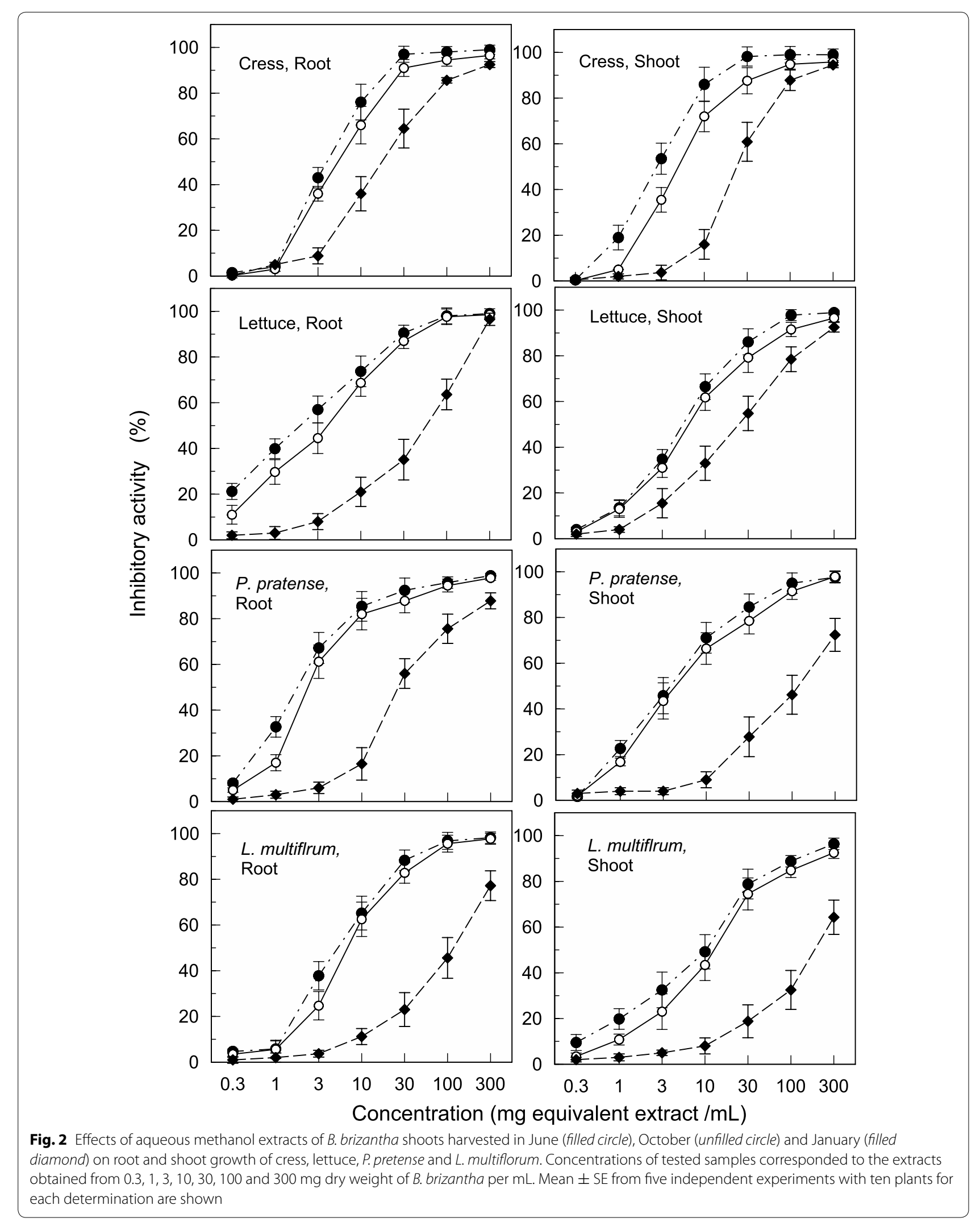


Table $1 I_{50}$ of aqueous methanol extracts of $B$. brizantha shoots harvested in June, October and January on root and shoot growth of cress, lettuce, $P$. pretense and $L$. multiflorum

\begin{tabular}{llcc}
\hline & \multicolumn{3}{l}{$\mathbf{I}_{\mathbf{5 0}}$ (mg equivalent extract $\left./ \mathbf{m L}\right)$} \\
\cline { 2 - 4 } & June & October & January \\
\hline Cress & & & \\
Root & 4.5 & 6.3 & 19.8 \\
Shoot & 2.8 & 4.9 & 22.3 \\
Lettuce & & & \\
Root & 2.5 & 4.5 & 55.7 \\
Shoot & 6.3 & 7.9 & 25.3 \\
P.pratense & & & \\
Root & 1.8 & 2.5 & 122.5 \\
Shoot & 4.4 & 4.7 & \\
L. multiflorum & & & 123.5 \\
Root & 4.9 & 7.2 & 211.3 \\
Shoot & 9.8 & 13.8 & \\
\hline
\end{tabular}

The values were determined by a logistic regression analysis after bioassays

the variety of agricultural settings to reduce dependency on synthetic herbicides. Natural products are considered to be more environmentally benign than most synthetic herbicides. Their environmental half-lives can be expected to be shorter, and the fact that they have been part of the natural environment suggests a lesser demand for regulatory measures (Duke et al. 2000). In addition, $B$. brizantha has been reported to have a potential to enhance mineral nutrients (Souza et al. 2006). Further studies are required to determine the effectiveness of $B$. brizantha on weeds in the field conditions.

\section{Conclusion}

The extracts of $B$. brizantha shoots harvested in June, October and January inhibited root and shoot growth of cress, lettuce, Phleum pretense and Lolium multiflorum in a concentration dependent manner. However, the inhibitory activity of $B$. brizantha of June and October was greater than that of $B$. brizantha of January. Concentrations of three allelopathic active substances, $\quad(6 R, 9 S)$-3-oxo- $\alpha$-ionol, $\quad(6 R, 9 R)$-3-oxo- $\alpha$-ionol and 4-ketopinoresinol were also greater in $B$. brizantha shoots of June and October than those in B. brizantha shoots of January. Therefore, $B$. brizantha could be useful for a weed suppressive residue or soil additive materials in the variety of agricultural settings to develop sustainable agriculture options due to those allelopathic active substances. The effectiveness of $B$. brizantha of June and October as a weed suppressive agent may be greater than that of January.
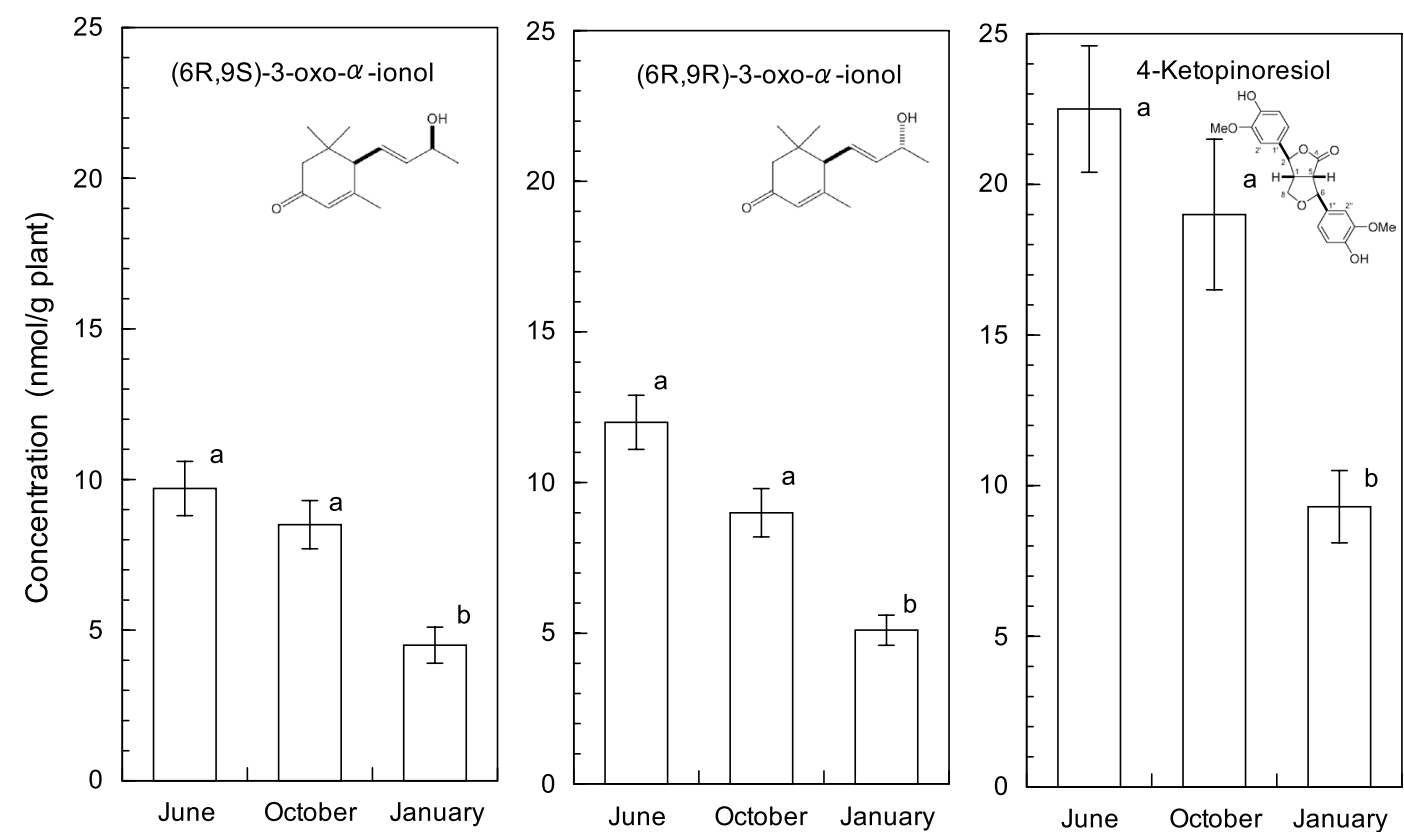

Fig. 3 Concentration of (6R,9S)-3-oxo- $\alpha$-ionol, $(6 R, 9 R)$-3-oxo- $\alpha$-ionol and 4-ketopinoresinol in B. brizantha shoots harvested in June, October and January. Mean \pm SE from three independent experiments with three quantifications for each determination are shown. The different letters in the same groups indicate significant difference $(P<0.05)$ according to Duncan's multiple comparison tests 


\section{Abbreviations}

$I_{50}$ : concentrations required for $50 \%$ growth inhibition.

\section{Authors' contributions}

$\mathrm{KA}$ is responsible for the whole experiments and wrote the article. HK-N is responsible for experimental design, result interpretation, made discussion and conclusion. Both authors read and approved the final manuscript.

\section{Acknowledgements}

The authors thank Dr. Fujii Y (National Institute for Agro-Environmental Science, Tsukuba, Japan) for giving us plant materials of B. brizantha. The authors thank Dr. Ohno O and Suenag K (Department of Chemistry, Keio University, Yokohama, Japan) for NMR analyses and specific rotation measurements of the compounds.

\section{Compliance with ethical guidelines}

\section{Competing interests}

The authors declare that they have no competing interests.

Received: 26 February 2015 Accepted: 27 August 2015

Published online: 19 September 2015

\section{References}

Bais HP, Weir TL, Perry LG, Gilroy S, Vivanco JM (2006) The role of root exudates in rhizosphere interactions with plants and other organisms. Annu Rev Plant Biol 57:233-266

Belz RG (2007) Allelopathy in crop/weed interactions_-an update. Pest Manag Sci 63:308-326

Bonanomi G, Sicurezza MG, Caporaso S, Esposito A, Mazzoleni S (2006) Phytotoxicity dynamics of decaying plant materials. New Phytol 169:571-578

Cook BG, Pengelly BC, Brown SD, Donnelly JL, Eagles DA, Franco MA, Hanson J, Mullen BF, Partridge IJ, Peters M, Schultze-Kraft R (2005) Tropical forages. CSIRO, Brisbane

Cooper R, Levy EC, Lavie D (1977) Novel germination inhibitors from Aegilops ovata L. J Chem Soc Chem Comm 21:794-795
D'Abrosca B, DellaGreca M, Fiorentino A, Monaco P, Oriano P, Temussi F (2004) Structure elucidation and phytotoxicity of $C_{13}$ nor-isoprenoids from Cestrum parqui. Phytochemistry 65:497-505

Duke SO, Dayan FE, Romagni JG, Rimando AM (2000) Natural products as sources of herbicide, current status and future trends. Weed Res 40:99-111

Inderjit (1996) Plant phenolics in allelopathy. Bot Rev 62:186-202

McGregor JT Jr, Smith RJ Jr, Talbert RE (1988) Broadleaf signalgrass (Brachiaria platyphylla) duration of interference in rice (Oryza sativa). Weed Sci 36:747-750

Kato-Noguchi H, Yamamoto M, Tamura K, Teruya T, Suenaga K, Fujii Y (2010) Isolation and identification of potent allelopathic substances in rattail fescue. Plant Grow Regul 60:127-131

Kato-Noguchi H, Kobayashi A, Ohno O, Kimura F, Fujii Y, Suenaga K (2014) Phytotoxic substances with allelopathic activity may be central to the strong invasive potential of Brachiaria brizantha. J Plant Physiol 171:525-530

Lavie D, Levy EC, Choen A, Evenari M, Guttermann Y (1974) New germination inhibitor from Aegilops ovata L. Nature 249:388

Macías FA, Molinillo JMG, Varela RM, Galindo JGG (2007) Allelopathy—a natural alternative for weed control. Pest Manag Sci 63:327-348

Martins D, Martins CC, Costa NV (2006) Allelopathic potential of solutions of soils cultivated with Brachiaria brizantha: effects on some pasture grass and weeds seeds. Planta Daninha 24:61-70

Miles JW, Maas BL, do Valle CB, Kumble V (1996) Brachiaria: biology, agronomy and improvement. CIAT, Embrapa, Brazil

Narwal SS (1999) Allelopathy in weed management. In: Narwal SS (ed) Allelopathy update, vol 2., Basic and applied aspectsScience Publishers Inc, Enfield, pp 203-254

Pabst A, Barrona D, Sémonb E, Schreier P (1992) Two diastereomeric 3-oxo- $\alpha$ ionol $\beta$-glucosides from raspberry fruit. Phytochemistry 31:1649-1652

Putnam AR (1988) Allelochemicals from plants as herbicides. Weed Technol 2:510-518

Rodrigues APDC, Laura VA, Pereira SR, Deiss C (2012) Allelopathy of two Brachiaria species in seeds of three species of Stylosanthes. Ciencia Rural 42:1758-1763

Souza LS, Velini ED, Martins D, Rosolem CA (2006) Allelopathic effects of Brachiaria decumbens on the initial development of seven crops. Planta Daninha 24:657-668

Weston LA (1996) Utilization of allelopathy for weed management in agroecosystems. Agron J 88:860-866

\section{Submit your manuscript to a SpringerOpen ${ }^{\circ}$ journal and benefit from:}

- Convenient online submission

- Rigorous peer review

- Immediate publication on acceptance

- Open access: articles freely available online

- High visibility within the field

- Retaining the copyright to your article

Submit your next manuscript at $>$ springeropen.com 